\title{
Ethnicity influences breast cancer stem cells' drug resistance
}

DOI:

10.1111/tbj. 13021

\section{Document Version}

Accepted author manuscript

Link to publication record in Manchester Research Explorer

\section{Citation for published version (APA):}

Kamal, M., Nafie, E. H. O., Elsers, S., Alanwar, S., Ibrahim, R., Farag, F., Mlees, M., Simões, B. M., Spence, K., Santiago-Gómez, A., Salem, M. L., \& Clarke, R. B. (2018). Ethnicity influences breast cancer stem cells' drug resistance. Breast Journal, 24(4), 701-703. https://doi.org/10.1111/tbj.13021

\section{Published in:}

Breast Journal

\section{Citing this paper}

Please note that where the full-text provided on Manchester Research Explorer is the Author Accepted Manuscript or Proof version this may differ from the final Published version. If citing, it is advised that you check and use the publisher's definitive version.

\section{General rights}

Copyright and moral rights for the publications made accessible in the Research Explorer are retained by the authors and/or other copyright owners and it is a condition of accessing publications that users recognise and abide by the legal requirements associated with these rights.

\section{Takedown policy}

If you believe that this document breaches copyright please refer to the University of Manchester's Takedown Procedures [http://man.ac.uk/04Y6Bo] or contact uml.scholarlycommunications@manchester.ac.uk providing relevant details, so we can investigate your claim.

\section{OPEN ACCESS}




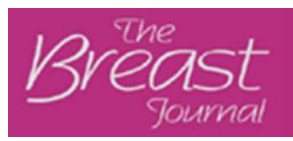

\section{Ethnicity influences Breast Cancer Stem Cells Drug Resistance}

\begin{tabular}{|c|c|}
\hline Journal: & The Breast Journal \\
\hline Manuscript ID & TBJ-00134-2017.R2 \\
\hline Manuscript Type: & Commentary \\
\hline Date Submitted by the Author: & 02-Apr-2017 \\
\hline Complete List of Authors: & $\begin{array}{l}\text { Kamal, Mohamed; Benha University Faculty of Science, Zoology } \\
\text { Nafie, Ebtesam; Benah University, Zoology } \\
\text { Elsers, Shimaa; Benha University Faculty of Science, Zoology } \\
\text { Alanwar, Salma; Benha University Faculty of Science, Zoology } \\
\text { Ibrahim, Rawayeh; Benha University Faculty of Science, Zoology } \\
\text { Farag, Fatma; Benha University Faculty of Science, Zoology } \\
\text { Mlees, Mohamed; Tanta University Faculty of Medicine } \\
\text { Simoes, Bruno; University of Manchester, Division of Molecular and Clinical } \\
\text { Cancer Sciences } \\
\text { Spence, Kath; University of Manchester, Division of Molecular and Clinical } \\
\text { Cancer Sciences } \\
\text { Santiago-Gómez , Angélica ; University of Manchester, Division of } \\
\text { Molecular and Clinical Cancer Sciences } \\
\text { Salem, Mohamed ; University of Tanta, Faculty of Science } \\
\text { Clarke, Robert; University of Manchester, Division of Molecular and Clinical } \\
\text { Cancer Sciences }\end{array}$ \\
\hline Key Words: & Breast Cancer, Cancer Stem Cells, Ethnicity, Drug resistance \\
\hline
\end{tabular}

\section{SCHOLARONE ${ }^{\text {I }}$}


Ethnicity influences Breast Cancer Stem Cells Drug resistance Mohamed Kamal ${ }^{1 *}$, Ebtesam H.O. Nafie ${ }^{1}$, Shimaa Elsers ${ }^{1}$, Salma Alanwar ${ }^{1}$, Rawayeh Ibrahim ${ }^{1}$, Fatma Farag $^{1}$, Mohamed Mlees ${ }^{2}$, Bruno M. Simões ${ }^{3}$, Kath Spence ${ }^{3}$, Angélica Santiago-Gómez ${ }^{3}$, Mohamed L. Salem ${ }^{4}$, and Robert B. Clarke ${ }^{3}$

${ }^{1}$ Department of Zoology, Faculty of Science, University of Benha, Egypt.

${ }^{2}$ Department of General Surgery, Faculty of Medicine, University of Tanta, Egypt.

${ }^{3}$ Breast Biology Group, Division of Molecular and Clinical Cancer Sciences, University of Manchester, England.

${ }^{4}$ Department of Zoology, Faculty of Science, University of Tanta, Egypt.

*Corresponding author: Mohamed Kamal; Email: m.kamal@fsc.bu.edu.eg; Telephone: +1 405-2135755. Current address: Rm 1413, BRC-W, Stephenson Cancer Centre, Oklahoma city, Oklahoma, United States.

\section{Acknowledgments:}

This study was funded by STDF Grant No. STDF-STF 6123 and Breast Cancer Now.

Up to $70 \%$ of Breast Cancer (BC) patients relapse within 5 years. Al-Hajj et al. reported that a subpopulation of cancer cells, Breast Cancer Stem Cells (BCSCs), has an inherent ability to resist drugs and cause relapse [1]. The biology of $B C$ have been shown to be different in patients from different ethnic populations [2]. This racial variation is specifically evident in BCSCs resistance to chemotherapy. In Vietnam, it was shown that CD44 is the main player in resistance of BCSCs to chemotherapy [3], whereas in Japan, ALDH1 was proven to have a strong association with resistance to drugs [4]. In this study, we tested the hypothesis that BCSCs are quantitatively different between European and African ethnic groups and they use different mechanisms to resist therapy.

Twenty three BC surgical specimens were collected (see compliance with ethical standards section). 17 patients were Egyptians and 6 were English. Patients were clustered into untreated (therapy naïve) and treated (patients who received neoadjuvant therapy or their tumour cells were incubated in vitro in media containing $1 \mu \mathrm{m}$ Doxorubicin for 16 hours). Egyptian patients were 11 untreated and 6 treated whereas English patients were 3 untreated and 3 treated. All patients had the same tumour histological type (Invasive ductal carcinoma) and were estrogen receptor positive (ER+).

Anoikis resistant cells (as a measure to BCSCs) were isolated as described by Shaw et al. [5]. Egyptian patients had nearly 2 -fold more BCSC numbers compared to English patients $(32 \% \pm 12.8$ vs. $18 \% \pm 4.3, p=0.13$ ) (Fig.1). This is the first study to compare BCSCs numbers between different ethnic groups. Our findings agree with a study found that African Americans colorectal cancer patients had $60 \%$ more CSCs compared to their Caucasian counterpart [6]. The relatively high numbers of BCSCs in Egyptian patients may explain the poor prognosis of BC in Africa compared to well-developed countries [7].

We then investigated the expression of 46 genes known to have roles in drug resistance (Supplementary Table 1) using StellARray qPCR Arrays. We found that all genes showed significantly higher expression in BCSCs from the untreated Egyptian samples compared to those from the English group (Supplementary Table 2). Our data show that it is not only BCSC content which differs across populations, but also their drug resistance mechanisms are different. This is the first study to compare 
gene expression of BCSCs between different ethnic groups. However, others reported that biology of BC is different in different ethnic groups, yet all these studies were on the level of bulk tumour cells.

Moreover, in the Egyptian group, NOTCH4 was the only gene showing a significant increase in its expression in treated patients compared to untreated patients (Table 1). In contrast, in the English group, NOTCH1 was the only gene showed a significant increase in its expression (Table 2). Previously we found that NOTCH4 knockdown caused greater reduction in CSC activity than NOTCH1 in the English patients [8] and NOTCH4 receptor activation mediates BCSC activity as a response to therapy [9]. The contradiction between the current study and our previous studies may be due to posttranscriptional and or posttranslational modifications of $\mathrm{NOTCH}$ signaling. Indeed the differential expression we detected in this study in NOTCH members among ethnic groups is on the level of mRNA expression, whereas our previous studies measured protein levels of expression and activity of NOTCH members. Our results recommend specific targeting for NOTCH1 and NOTCH4 in the English and Egyptian patients, respectively.

In conclusion, we were the first to show that BCSCs are qualitatively and quantitatively different in different ethnic groups which may explain the racial variation in BC behaviour and biology. This is a pilot study with a limited number of patients and therefore these findings would have to be further validated on a larger cohort of patients.

\section{Compliance with Ethical Standards:}

English samples were collected via Manchester Cancer Research Centre Biobank which has been ethically approved by the South Manchester Research Ethics Committee (Ref: 07/H1003/161 + 5). Collection of Egyptian samples has been ethically approved by the Research Ethics Committee, Faculty of Medicine, University of Tanta (Code: 3012/01/15).

\section{References:}

1. Al-Hajj, M., et al., Prospective identification of tumorigenic breast cancer cells. Proc Natl Acad Sci U S A, 2003. 100(7): p. 3983-8.

2. Amend, K., D. Hicks, and C.B. Ambrosone, Breast cancer in African-American women: differences in tumor biology from European-American women. Cancer Res, 2006. 66(17): p. 8327-30.

3. Van Phuc, P., et al., Downregulation of CD44 reduces doxorubicin resistance of CD44CD24 breast cancer cells. Onco Targets Ther, 2011. 4: p. 71-8.

4. Tanei, T., et al., Association of breast cancer stem cells identified by aldehyde dehydrogenase 1 expression with resistance to sequential Paclitaxel and epirubicin-based chemotherapy for breast cancers. Clin Cancer Res, 2009. 15(12): p. 4234-41.

5. Shaw, F.L., et al., A Detailed Mammosphere Assay Protocol for the Quantification of Breast Stem Cell Activity. Journal of Mammary Gland Biology and Neoplasia, 2012. 17(2): p. 111-117.

6. Leavell, B.J., et al., Associations between markers of colorectal cancer stem cells and adenomas among ethnic groups. Dig Dis Sci, 2012. 57(9): p. 2334-9.

7. Shavers, V.L., L.C. Harlan, and J.L. Stevens, Racial/ethnic variation in clinical presentation, treatment, and survival among breast cancer patients under age 35. Cancer, 2003. 97(1): p. 13447.

8. Harrison, H., et al., Regulation of breast cancer stem cell activity by signaling through the Notch4 receptor. Cancer Res, 2010. 70(2): p. 709-18.

9. Simoes, B.M., et al., Anti-estrogen Resistance in Human Breast Tumors Is Driven by JAG1NOTCH4-Dependent Cancer Stem Cell Activity. Cell Rep, 2015. 12(12): p. 1968-77. 
Table 1: Genes showed significant difference in their expression between BCSCs from treated and untreated Egyptian patients

\begin{tabular}{|c|c|c|c|c|c|}
\hline \multicolumn{3}{|c|}{ Down-regulated genes } & \multicolumn{3}{|c|}{ Up-regulated genes } \\
\hline Gene & $\begin{array}{c}\text { Fold } \\
\text { Decrease }\end{array}$ & Function & Gene & $\begin{array}{c}\text { Fold } \\
\text { Increase }\end{array}$ & Function \\
\hline BMI1 & 1.5130362 & \multirow[t]{6}{*}{ Proliferation } & $\mathrm{NOTCH} 4$ & 3.50224 & CSC Signaling \\
\hline CDK2 & 1.1117699 & & & & \\
\hline CDKN1A & 0.767426 & & & & \\
\hline VEGFA & 1.12864667 & & & & \\
\hline CCNB1 & 1.1498215 & & & & \\
\hline MMP9 & 0.852149 & & & & \\
\hline HIF1A & 1.6078917 & \multirow[t]{5}{*}{ Transcription } & & & \\
\hline NFKB1 & 1.024524 & & & & \\
\hline NANOG & 1.160355 & & & & \\
\hline STAT1 & 1.168615 & & & & \\
\hline SHH & 0.798564 & & & & \\
\hline CD44 & 1.330462 & \multirow[t]{2}{*}{ CSC Signaling } & & & \\
\hline JAG1 & 1.0351375 & & & & \\
\hline MET & 1.93902847 & Metastasis & & & \\
\hline DNMT1 & 4.363427 & \multirow[t]{2}{*}{ DNA methylation } & & & \\
\hline DNMT3B & 0.834107 & & & & \\
\hline BCL2 & 1.273736 & apoptosis & & & \\
\hline
\end{tabular}

Fold change values are displayed with respect to the treated patients. $p$ value $\leq 0.05$ was considered significant. 
Table 2: Genes showed significant difference in their expression between BCSCs from treated and untreated English patients

\begin{tabular}{|c|c|c|c|c|c|}
\hline \multicolumn{3}{|c|}{ Down-regulated } & \multicolumn{3}{c|}{ Up-regulated } \\
\cline { 1 - 3 } Gene & Fold Decrease & Function & Gene & Fold Increase & Function \\
\hline GLI1 & 0.849724 & GLI family zinc finger 1 & \multirow{2}{*}{ NOTCH1 } & 8.33958 & \multirow{2}{*}{ CSC signaling } \\
\cline { 1 - 3 } IL10 & 0.978846 & Inflammation & & & \\
\hline
\end{tabular}

Fold change values are displayed with respect to the treated patients. $p$ value $\leq 0.05$ was considered significant. 